Österreichische Akademie der Wissenschaften / Austrian Academy of Sciences AAS WORKING PAPERS IN SOCIAL ANTHROPOLOGY Volume 13

Mohammed Shunnaq TOURISM - BENEFITS FOR MANY, PROBLEMS FOR SOME?

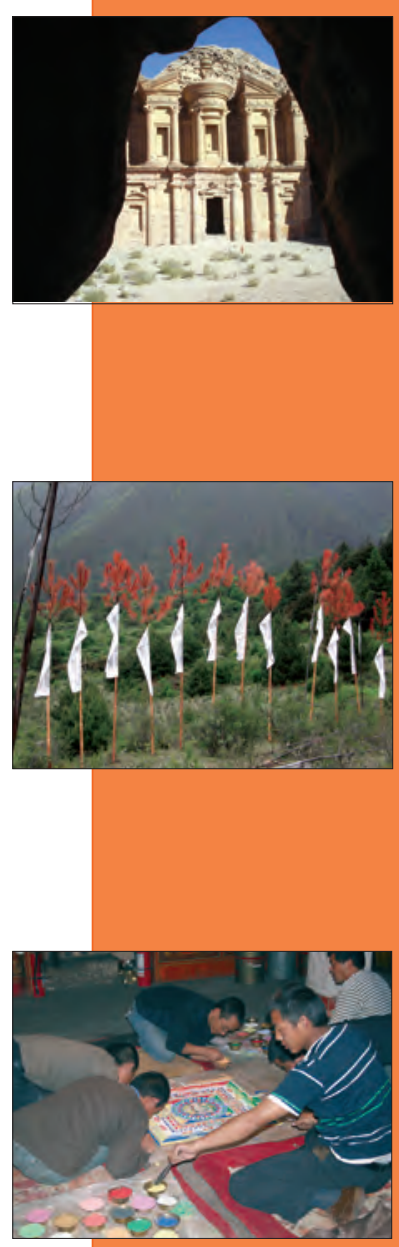

\author{
Anthropological Insights \\ through Case Examples from Jordan
}




\section{AAS Working Papers in Social Anthropology / \\ ÖAW Arbeitspapiere zur Sozialanthropologie}

ISSN: $1998-507 \mathrm{X}$

doi: 10.1553/wpsa13

ISBN: 978-3-7001-6820-1

Wien 2010

\section{Editors / Herausgeber:}

Andre Gingrich \& Guntram Hazod

(C) Institut für Sozialanthropologie

Zentrum Asienwissenschaften und Sozialanthropologie

Österreichische Akademie der Wissenschaften

Prinz-Eugen-Straße 8-10

A-1040 Wien

Fax: 01/ 51581-6450

E-Mail: sozialanthropologie@oeaw.ac.at 


\title{
TOURISM - BENEFITS FOR MANY, PROBLEMS FOR SOME?
}

\author{
Anthropological Insights through Case Examples from Jordan*
}

\author{
Mohammed ShunnaQ
}

Tourism has grown rapidly over the past two decades and the World Tourism Organization reports it to be one of the world's most important sources of employment and of Gross Domestic Product. In 2001, some 207 million workers worldwide worked in the tourism sector and the combined GDP totaled US \$3.5 billion, or about 11 percent, of the world's total (Natsios 2008). The United Nation's World Tourism Organization (UNWTO) forecasts a steady increase in tourism during the next decade expecting it to reach nearly 1.6 billion international arrivals by the year 2020 (UNWTO 2009). The Middle Eastern Region has had its share of tourism and has witnessed a steady increase of tourists over the past years mainly due to the amount of exposure it has been receiving. As for Jordan, tourism has become of vital importance to its economy, but despite of its benefits, the rapid increase of tourism has caused some problems.

This research attempts to examine the relationship between the Jordanian insiders (Hosts) and the outsider foreigners (Guests), particularly after the signing of the peace treaty with Israel in October 1994. The policy was to open doors wide for tourists. Many believe that increasing the number of tourists visiting Jordan will be a big asset to the Jordanian economy. The development of tourism plans were designed and put together by the Americans and the Japanese in cooperation with the Jordanian Ministry of Tourism and Antiquities (MoTA) (established in 1988 and originally the Department of Tourism since 1965), with the aim of increasing the number of tourists visiting Jordan. Theoretically, this should help Jordan prosper. On the practical level it seems to have turned into a one-sided business in which the local population is rarely included and the national patrimony suffers. Those interested in the protection of cultural resources are concerned with the position of the country's cultural heritage amidst the international desire to invest in Jordan's tourism sector. The study will explain how international agencies use the cultural heritage resources in Jordan and what functional role the big international agencies which are interested in the Jordanian patrimony play. The paper will also identify the regions of most interest to international agencies and their development initiatives in these selected territories while other parts of the country--equally rich in cultural resources - have been sadly neglected. The study finally recommends that international investors focus on the development of promising historical and archaeological sites in Northern Jordan provided that they use the sustainable tourism approach.

\section{About Jordan}

Geography and Demographics

The Hashemite Kingdom of Jordan is located in SW Asia and is bordered by Syria (to the North), Iraq (to the Northeast), Israel and the West Bank (to the West), and Saudi Arabia (to both East and South). The Kingdom's population is ca. 7 million people, including individuals of Palestinian

\footnotetext{
* The present article is based on a paper presented at the Institute for Social Anthropology of the Austrian Academy of Sciences, Dezember 14, 2009. The map and pictures presented in this paper are the courtesies of Mawafaq Bataineh and Hussein Al-Zoubi, Faculty Archaeology and Anthropology, Yarmouk University.
} 
(47\%), Jordanian (30\%), and Iraqi (14\%) origin. Arabic is Jordan's official language, though many people also know English. French has recently been introduced in schools. Jordan's climate is mostly desert, with primary bodies of water limited to the Dead Sea, Jordan River, and Gulf of Aqaba. Jordan is 89,213 sq.km in size, with an urban population of over $78 \%$ mainly located in four out of twelve governorates: Amman (capital), Balqa, Zarqa, and Irbid.

Politics

In 1946, Jordan declared its independence from Britain. Jordan is a constitutional monarchy and has a legal system that is based on Islamic law and French Civil Code. The Government of Jordan legalized political parties in 1992. In 1948, 1967, and 1973, Jordan engaged in a number of wars with Israel that finally led to the 1994 Israeli-Jordanian Peace Treaty. With its pro-Western orientation, Jordan tries to avoid regional conflict as much as possible. Although Jordan maintains internal political stability, the country is vulnerable to external, regional political instability.

\section{Why Preserve National Heritage?}

The main reason for preserving cultural heritage is because it is the bearer of the values that make part of the history and the memory of mankind that must be handed over to future generations. This heritage is the material carrier of those values that sometimes are immaterial and present the deepest feelings and beliefs of a culture. Besides, cultural heritage has acquired a new significance in the last decades by means of the quick development and growth of cultural tourism. This type of tourism can either threaten the preservation of this heritage, or aid the sustainable development of the country as it will assist in providing the necessary funds for the preservation of this heritage.

To guarantee a correct approach it is necessary to work on different aspects such as increasing the awareness of people and decision makers simultaneously. It is of utmost necessity to identify, make recognizable and understandable the values that a monuments bear which justify its preservation. People will not preserve nor will pay attention to something that they do not value or esteem, and nobody will value something that they cannot understand. In the end, people only conserve what they love and they can love only what they understand. The understanding, in turn, comes mainly from education and the promotion of cultural awareness.

\section{Jordan and Tourism}

During the past decade tourism in Jordan has been steadily growing and has become a major source of income and employment. According to MoTA 2009, this sector contributed more than US $\$ 800$ million to Jordan's economy and accounts for approximately $10 \%$ of the country's gross domestic product (GDP). Employment in the in the tourism sector in 2009 was estimated at around 130,000 ( $11 \%$ of the work force).

The history of tourism in Jordan extends back to the 4th Century when Christian pilgrims started arriving to see the church built on Mount Nebo. Until today, Jordan offers countless tourist destinations in a multitude of areas across the country, but many potentially successful ones are still in need appropriate development.

\subsection{Tourism Resources in Jordan}

Jordan is unique in the area for the abundance and variety of tourist attractions. The country has innumerable archaeological sites which are of significant interest not only to researchers and specialists in the field, but also international tourists coming from all over the world with special 
interests. Some are eager to enjoy the the Aqaba region with the beautiful desert scenes and the unique rose-red Nabatean city which has been chosen as one of the seven new world wonders recently; others prefer to trace the history of ancient civilizations; and still others favor to indulge in the numerous hot springs all across Jordan. The environment has also become a major interest in the natural reserves distributed throughout Jordan.

These resources can be classified into the following categories:

1. Natural Resources: these include areas of significant land/sea-scapes, these include: Aqaba, Wadi Rum and natural reserves spreading in many regions. Such tourism, eco-tourism, encourages interest in the established reserves to study the flora and fauna there. Examples of Reserves are Dana, Birqish, Al-Azraq, Al-Mujib Valley, Wadi Rum, and Al-Shoumali.

2. Cultural Resources: these include mainly archaeological/historical sites, shopping, galleries, events, and handcrafts.

3. Therapeutic Resources: these are composed of the Dead Sea, Himma, Ma'een and some locations where waterfalls and hot springs are found.

4. Medical Tourism: These tourists come mostly from Arabic countries from North Africa and the Arabian Peninsula seeking treatment in Jordanian hospitals. (Jordan has two internationally accredited hospitals in Amman).

5. Religious tourism: Visiting a variety of religious sites, five of which were designated by the Vatican as holy sites for Christian pilgrims: Mar Elias, the Lady of the Mountain, Mount Nebo, the church of the map in Madaba, and the Baptism Site.

3.2 The Principles and Policies of Tourism in Jordan

There are four guiding principles that lead the progress of the tourism sector in Jordan. According to the report by ESCWA (2001), these are:

1. Understanding that tourism is a prime component of the Jordanian economy.

2. There is a willingness to diversify tourist attractions and transform them from antiquities to that of a general culture base, which is a requirement of new forms of tourism becoming so familiar around the world.

3. Positive and sustainable conservation of different resources.

4. Maximizing the complementary nature of both governmental and private sectors.

Such principles require some policies to become possible, these are characterized by:

a. Developing the tourism industry in Jordan as the main factor in the growth of the national economy.

b. Assuring the availability of quality infrastructure services, which includes hotels, resorts, restaurants, and basic amenities, which will lead eventually to the increase of investment in tourism sector.

c. The diversification of the Jordanian tourism product through new forms of development regarding cultural resources; which are mainly composed of archaeological, historical and religious sites; in addition to the creation of new types of natural, scenic and therapeutic activities. This will be supported by the progress to be achieved in urban activities as meetings, incentives, conferences and events. For those tourists, mainly coming from the Gulf countries who are driven mostly by leisure and recreational activities, restaurants, outdoor cafes and malls have been created in major cities around the country.

d. Increasing the opportunities of investment and cooperation with the private sector. 


\subsection{The Problems and Obstacles Facing Development of Tourism in Jordan}

There are some main problems and threats regarding tourism development in Jordan as indicated by some previous reports (ESCWA, 2001; Roudan et al., 2000; and JICA, 2004), these can be summarized as the following:

1. The lack of awareness by a big segment in the Jordanian society about the importance of tourism and its activities.

2. Ignoring Jordan as an independent tourist destination and treating it rather as an extension of tour packages to neighboring countries.

3. The lack of facilities in many sites and destinations, and if existing, there is an in-adequate distribution of them.

4. The lack of promotional campaigns and marketing representatives abroad.

5. The high cost of domestic tourism, especially with the low income of a considerable segment in the Jordanian society.

6. The weak organizational structure for many frameworks involved in tourism development with a lack of funding.

7. Problems in training staff and employees, especially when it comes to some services and sustainability of resources.

There are some other major problems, especially for what is related to some particular kinds of destinations, such as archaeological and historical sites, which form a basic component in the group of attractions in Jordanian tourism. Such problems are characterized by agricultural expansion, urban development and rapid population growth. These problems in addition to the high unemployment, the wide spread lack of awareness about the importance of archaeological remains, are all creating real threats to archaeological sites. Also the inappropriate behavior of visitors in some destinations, which is characterized by littering, vandalism, and uncontrolled movement within the site, not only effects the quality of the visits, but can ultimately lead to the loss of both, the site and the tourist.

The least numbers of visitors were actually for museums, which might indicate the need to focus on their promotion and the level of their services (such as their presentation methods, interpretation and promotion); the Citadel Museum (Jordan National Museum) and Folklore Museum are the only two museums recording a growth in visitation, though they still need more development.

It becomes important then to supply areas with tourism services and to train local people to work in them, which will enhance living quality in these areas.

\subsection{Tourism and Local Communities}

On the national level, Jordan uses tourism as a major means of securing economic growth, but the benefits of tourism have been meager at the local level. Very few socio-economic experiments in Jordan have dealt with economic growth through community development and cultural resource management - two successful strategies for involving and enhancing local participation. Community-based tourism (Shunnaq, Schwab \& Reid 2008) is important for several reasons:

- It generates jobs and income for local communities and raises the living standards and quality of life of community residents while simultaneously benefiting the regional and national economies.

- It improves the local infrastructure, facilities, and services, as well as enhances the skills of local residents. 
- It makes residents stakeholders and educate the local population about the importance of the cultural heritage. Communities that benefit from tourism support it and are more ready to cooperate to preserve heritage.

- It provides incentives and revenues for the local population; this will lead to the consideration of national heritage as a treasure to safeguard rather than a booty to loot.

- It builds a sense of community and contributes to local cultural identity and traditions.

- It encourages niche tourism markets in cultural tourism, one of the most rapidly-growing segments of the international tourist market.

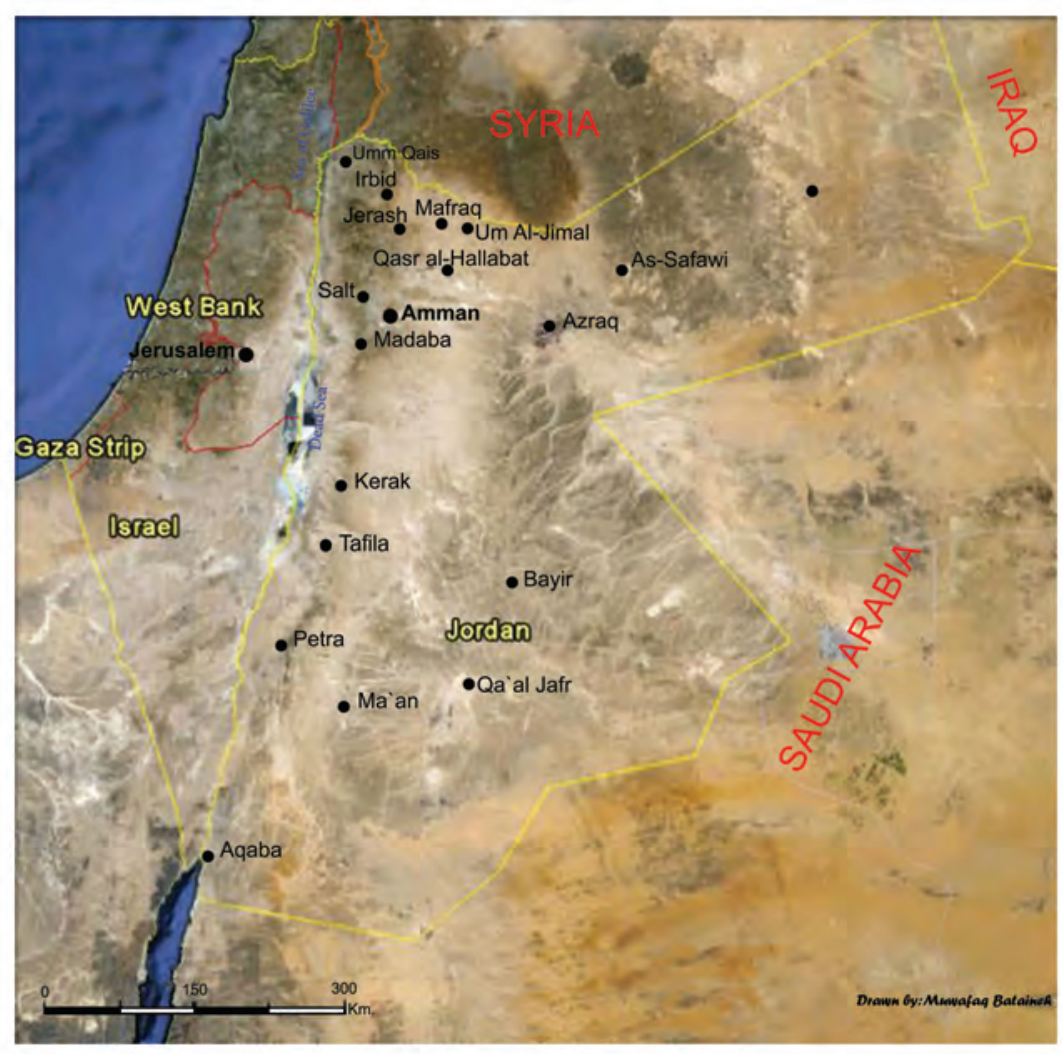

Fig. 1

Jordan and its main tourist sites.

\subsection{Tourist Zones}

The anthropological literature its full of different case studies about the tourism impact on a variety of destinations, negative or positive and its consequences in different countries in the world (Cohen 1992, 1988; Crick 1989; Farrell 1979; Richter 1989; Turner and Ash 1976; De Kadt 1979). Most are very hesitant to encourage the use tourism as the only way of economic development for the countries and many consider it a dangerous means to raise the money necessary for the conservation and preservation of the cultural heritage. Nevertheless, such concerns have not been studied seriously before the international agencies were given permission to divide Jordan into tourist zones and develop them according to their assessment.

The first step was for the Ministry of Tourism and Antiquity to divide the country into three tourism regions in 1996: the central region (including Amman, Zarqa, Karak, Madaba, The Dead Sea and the Desert castles); the southern region (Petra, Wadi Rum, Aqaba, and Tafiila); and the northern region (Irbid, Jarash, Ajluon, Umm Qais, and the Jordan Valley). These tourist zones are not given equal attention by the local government and the Ministry of Antiquities and tourism, on the one hand, and international agencies on the other. 
The first zone, the central region, is the predominant one of the country. Since it includes the capital with the international airport, the entire foreign diplomatic body, and most governmental or private institutions, the central region has become the country's aorta.

The second tourism zone is the southern region which embraces a number of important tourism destinations. In this zone is located the historical rose-red city of Petra - one of the most unique places in the world and the marvel of the tourism industry in Jordan. In the southern region is also located the only port to the Red Sea. Aqaba, as it is called, is not only an important tourist destination, much liked for its mild climate in the winter, but also plays a major role in the Jordanian economy as the import and export goods and merchandise takes place there mainly. It is also important to mention that Aqaba is the bridge between Jordan and Israel. The Jordanian government constructed a highway connecting Aila (the Jordanian side) and Israel. Travel agents promote tourism to Israel, offering a one day visit to Israel if tourist groups visit Petra. This one-day-courtesy-visit to Israel is used as a propaganda to increase the number of visitors to the southern tourist zone.

The third area is the northern region of the country which is until now considered the least important on the tourist map. The government largely ignores the importance of this region in the tourism sector even though it contains many archaeologically and historically important sites and has a vast diversity of environment. In this part of the country we can clearly see the cultural interchange between the West and East throughout history. Nevertheless, archaeological sites and cultural resources are given only little attention. The conservation, preservation, and management of these sites need to be carefully studied and implemented to save these sites and prolong their presence as part of human history. Most archaeological sites in this region are sealed, once again, after excavation to preserve them from looting or any possible damage since the government does not have the necessary budget or executive plans to develop this region for tourism or conserve the excavated sites. Sites which stay exposed to people or weather conditions deteriorate rapidly such as the tomb paintings of Abila. Some other tomb paintings in the Northern region such as the ones in the village of Soum have deteriorated to a degree of total erasure due to their exposure to oxygen over the past decade. The formation of fungi on the interior walls and ceiling has lead to an irrevocable damage. Many other sites are facing the same doom.

\subsection{Foreign Agencies Developing the Tourism Sector in Jordan}

After the First Golf War, many foreign agencies offered to aid the Jordanian government in solving its economic problems caused by the political tribulations in the region. Here I would like to concentrate on two of these agencies who have made one of their main aims the development of the tourism sector in Jordan. These agencies are the Japanese International Cooperation Agency (JICA) and the United State Agency for International Development (USAID). Both developed plans to improve the tourism sector industry in Jordan. Questions will be raised about to what extent these agencies have considered the long-term conservation and preservation of the Jordanian Patrimony and its cultural identity at the time of developing and implementing their strategies in the Host country. Following is a presentation of both JICA and USAID's function and history in Jordan.

\section{The Japanese International Cooperation Agency (JICA)}

In early 1996, JICA presented a study in four volumes suggesting how to develop the tourism sector in Jordan. This plan was based on the following strategy to develop tourism in the country: 1. Development plan and national tourism strategy until the year 2010, 2. Development of tourism 
plan for a specific area according to their priorities. The first priority for JICA, was to establish a national museum and create a tourist zone in the down town area of Amman (capital of Jordan); restore and upgrade the Ottoman part of the province; establish panoramic site seeing; establish a center with a rest area and a museum in the Dead Sea zone; build a highway to connect the Dead Sea with Madaba City (the city of impressive Byzantine mosaics); upgrade and modernize the access to the city of Al-Karak by upgrading streets for tourists and by establishing a visitor center with an observation quarter which will enable tourists to contemplate the city and the castle; establish proper security and tourist facilities. Later the same year, the agency presented a report which had a great impact on various local ministries. Hoping to find an adequate solution for the development of the tourism sector in Jordan, the government gave JICA the green light to finance the six proposed projects with a proposed total cost assessment of \$76 million. This amount is not the total sum of the Japanese investment in site development plans in the Kingdom of Jordan since the 1990s. JICA has invested a total of \$263 million in the period 1992-2010. Its projects included in addition to the six above mentioned ones the development of Salt, Umm Rasas Church, and AlAbdali infrastructure (down town Amman) among others.

Before any action can be taken or any construction work can be performed in down town Amman, some demolition is necessary. For example, the current archaeological museum at the citadel in Amman contains no adequate place for storing the many artifacts and other finds. This is a serious problem not only in Amman, but throughout Jordan and will only be solved when the new Japanese financed National Museum will open its doors and the artifacts located in small museums all over the country will find a permanent home there.

Those familiar with Jordan, will note that all of the JICA projects are concentrated in the central tourism area of the country. The northern region was excluded from the projects and plans of this agency, because this region had already been studied by the same agency in the Nineteen-Eighties and they had rendered it as not profitable enough and not suitable for their goals. As to the southern region ( Petra, Aqaba and Wadi Rum), JICA had previously declared that without Petra the tourism industry would never happen in Jordan (JICA 1996: 2-21).

One would expect from such a pronouncement that this agency would definitely look for its interests in this area; however, knowing the environmental limitations of the southern region for development and the big international attention focused on this region, JICA choose to leave this region to others who are more interested in it. The ministry of tourism and Antiquity (MoTA) published information in 1996 asserting that Petra received almost 50\% of the foreign technical and financial aids given to the country (Ministry of Tourism and Antiquity 1996: 48). Another area which could have been of interest to JICA in the southern region is Wadi Rum which is part of the Aqaba special economic zone. This means that Wadi Rum belongs to a different authority and jurisdiction status and this was one of the main reasons for JICA to refrain from investing in this area. In addition, the regional authorities of Aqaba did not agree to the proposal presented by JICA, because this agency had been extremely selective in choosing areas of interest for development and had excluded other areas of much need for development. The Japanese's immediate goal was to the develop areas of high potential to render tourism profit; Amman has been their initial target.

2. United States Agency for International Development (USAID)

The USAID/Jordan Tourism Development Projects (Siyaha) are in three phases: The first project, Siyaha I (2000-2004), the second, Siyaha II (2005-2008), and the third, Siyaha III (2009-2012). 
The first project was a preparatory phase in which the general goals of the National Tourism Strategy were defined in cooperation with the MoTA. Since tourism is an essential source of income for Jordan which is a country that generally lacks natural resources in contrast with so many neighboring countries, the MoTA in cooperation with USAID developed a national strategy which aimed at marketing Jordan nationally and internationally and focusing on product development and human resource development.

The objectives stated by Jordan's National Tourism Strategy, which was adopted in 2004, can be listed as follows:

1) Increase tourism receipts from JD570 million in 2003 to JD1.3 billion (US\$ 1.84 billion).

2) Increase tourism-supported jobs from 40,791 in 2003 to 91,719 in 2010, thus creating over 51,000 jobs.

3) Achieve taxation yield to the government of more than JD455 million (US\$ 637 million).

In order to achieve such objectives, the Jordanian government is considering the allocation of $4 \%$ of the national tourism receipts in order to enhance the promotion for its tourist destinations, developing them and integrating more human forces in the tourist industry.

The second project is a three-year project (2005-2008) that aims to assist Jordan in the implementation of the National Tourism Strategy (NTS 2004-2010). The funds for this phase total US\$17, 424, 283. The overall goal of this project is to promote Jordan's competitiveness as an international tourism destination by establishing the proper institutional and regulatory framework that enables privatesector driven investment and development, and stimulates tourism growth while preserving national tourism assets and the overall environment. The American agency has been working in close cooperation with the MoTA and other stakeholders to develop key tourism products and destinations in Jordan and strengthen the capacity of tourism institutions to lead and guide the sector.

The third project is a US $\$ 38,3$ million dollar project focusing on local communities and handicrafts through tourism sites. It aims at raising the workforce from 28,000 in 2005 to 62,500 in 2012. According to the USAID report in 2009, the workforce in the tourism sector totaled 42,200 jobs with 3.7 million tourists visiting tourist attractions in Jordan; 1.7 million of which were domestic tourists. The tourism income in 2009 has been estimated 2.1 billion JDs which makes up 14.7\% of the country's GDP (USAID 2009). The discrepancy between the MTA and the USAID statistics for 2009 seem to be caused by inaccuracies in the databanks of local ministries and international agencies.

The USAID proposals are to increase the facilities for the visitors in the down town of Amman, in Petra, and the museum complex of Madaba. This project includes exposition constructions and site seeing points, assessment plans of different sites, formation programs for all workers and upgrading the equipments. The recommendations presented by the USAID in their proposal, are similar to the ones presented by the National Park Service in United States of America in the year 1967. The main problem this agency has been facing is the long bureaucratic procedures which cause the plans, proposals, studies, and recommendations to be circulated among ministries and concerned parties without taking prompt actions. As is usually the case in many third world countries, the plans and recommendations never see the light and finally get filed in archival folders without implementation. Negotiations for compensation and reconstruction have also been slow. To start the constructions in Madaba, for example, the negotiations with the locals took more than six years and some of these issues are not solved yet. 
Another goal in the USAID projects is Nature-Driven Rural Development in the Southern Region Project, which will link three of Jordan's attractions - Petra, Dana and the newly protected area of Jebel Mas'uuda - to form a world-class tourism complex. The third goal to be achieved is a project for Cultural and Environmental Tourism; the U.S. National Park Service will work with the Jordanian government and local communities on strengthening the capacity of cultural and environmental tourism sites to enhance the tourism experience while assuring that environmental, natural, and cultural resources are protected.

During the implementation of these phases, a number of issues were exposed. Firstly, private foreign entities were in charge of serving tourists excluding the involvement of local institutions which was defeating some of the local government's primary goals. Secondly, the high centralization of patrimony registration, and the complicated bureaucracy inside the governmental bodies lead to a realization among the USAID officials that it is next to impossible implement decisions or take action or control without tedious bureaucratic procedures. Thirdly, USAID was prevented from compensating Jordanian government officials, administrative staff or office clerk for any work performed on the project apart from their ordinary job responsibilities. This, in turn, lowered the level of enthusiasm within government bodies among staff members who were charged with additional paper work by the project managers. Fourthly, USAID officials decided to place specialists and knowledgeable individuals in the field of interest under their wing to utilize their experience, knowledge and personal connections in the favor of the projects. These individuals were offered high-paid jobs with USAID in order to leave their low-paid positions in their local institution and work directly on the project with the foreign agency. Another issue of great concern which is, however, never tackled directly is the Islamic restrictions in food and beverage (Din 1989; 1988). USAID has plans to establish a culinary school to train future staff for hotels and gastronomy in the Middle East to ensure improvement and upgrade.

These proposals, however, unfortunately exclude some regions in Jordan which have a very rich cultural heritage, but are not located near Amman or Petra. These sites would have great potential for tourism if international agencies would be willing to allocate funds to develop these areas and place them on the tourist destination maps. One such magnificent site in northern Jordan is Umm al Jimal.

\section{Umm al Jimal as a proposed investment area in Northern Jordan}

Jordan has few natural resources but contains one of the highest concentrations of monuments and archaeological sites in the world, which must be considered one of its principal assets. Tourism has flourished in Jordan, but the majority of tourists visit the southern part of the country. Northern Jordan contains an extremely high concentration of well-preserved archeological sites and a unique landscape. In fact the archeology of this area reflects human settlement from the last half-million years, including Paleolithic, Neolithic, Bronze Age, Iron Age, Roman, Byzantine, Early Christian, and Islamic sites.

Nevertheless, tourism has not developed in Northern Jordan. This is mainly due to the lack of facilities for the interpretation and presentation of the region's rich cultural heritage. As has been described earlier, Northern Jordan lacks the infrastructure to support large-scale tourism.

Umm al Jimal is a potential tourism area in an impoverished desert area in Northern Jordan. Families in this area subsist on some of the lowest incomes in Jordan, and the communities, 
dominated by large families, are almost exclusively dependent on agriculture. The area, however, contains a host of undeveloped assets such as acres of monuments, local heritage, and desert life. Umm al Jimal is known as the Black Oasis because of the black basalt rock from which many of its houses, churches, barracks, and forts were built. Nearly no tourist infrastructure exists at this site. There is an Antiquity Department Office and a Tourism Department Office which both provide information for tourists about the whole area. Close to them are toilets for employees which are used by tourists. Souvenirs are sold in a tent where also some tea is served for visitors.

\subsection{Profile of Umm al Jimal}

\section{Location}

The small village of Umm al Jimal adjoins the major archaeological site of the same name. Located $20 \mathrm{~km}$ east of Mafraq and $86 \mathrm{~km}$ northeast of Amman (Fig. 1), it is located on the edge of a series of volcanic basalt flows that slope down from Jebel Druze, a mountain $50 \mathrm{~km}$ to the northeast. The archaeological site spans approximately 800 meters by 550 meters.

\section{History}

The ancient city of Umm al Jimal was built from black basalt stone and was occupied continuously for hundreds of years until circa $750 \mathrm{CE}$. Touring the city, visitors see evidence of ruins from the Early Roman and Byzantine periods as well as considerable Nabataean influence. The city's importance lasted through the Umayyad Period due to its proximity to the Desert Castles and the Pilgrim Route. In the fifth century, it was a prosperous agricultural and commercial center. In the sixth century, fifteen Christian churches were built. Destroyed by earthquake during the Islamic Period, Umm al Jimal was not rebuilt because the seat of government had shifted to Baghdad under the Abbasid Caliphs.

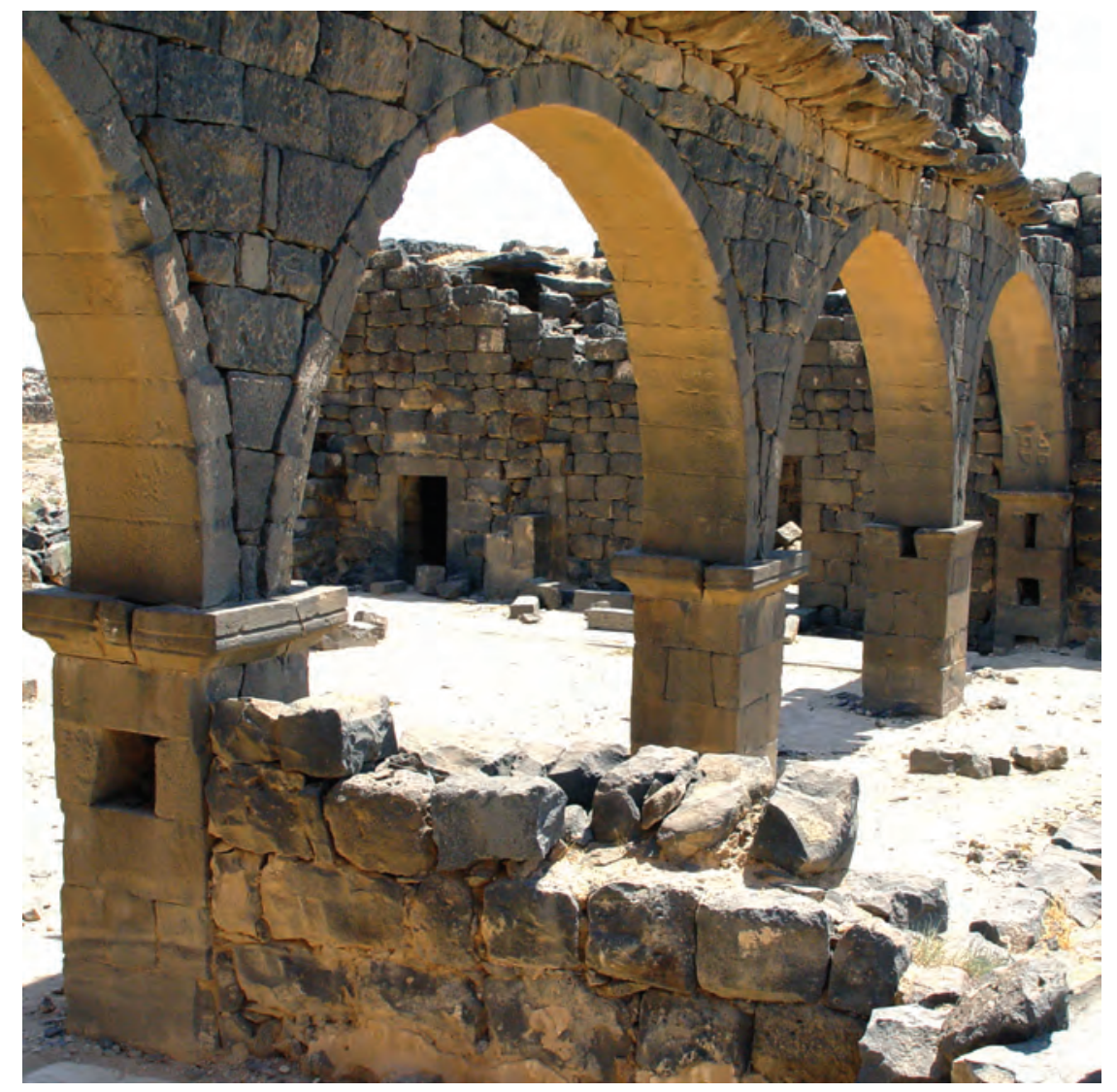

Fig. 2

Ruins of the ancient city of Umm al Jimal. 
Modern Umm al Jimal is a small, isolated village adjacent to the archaeological site. Local government provides most basic municipal services.

Natural, Cultural, and Heritage Assets

The archaeological site is the major tourism asset in the area. The site's large expanse makes it difficult to cover in one visit. The site includes the West Church, the Cathedral, the Praetorium, the Double Church, the North Church and Northeast Church, the Barracks, a number of houses, and the Reservoir. Beautiful arches with carved crosses still stand in the West Church. The Praetorium, a Roman civic building, is under restoration. Unfortunately, tourists are provided with little signage and no interpretation. Walking paths are in poor condition.

The potential for desert and eco-tourism around Umm al Jimal is good. The area offers a diverse desert ecology including a major bird flyway. Several rare species of birds can be seen in the region seasonally. Bedouin cultural tourism holds promise for future development despite the modernization of their lifestyle. Among potential tourism products are horse and camel rides, hunting, and desert living experiences with Bedouin clans. Archaeological tourism with emphasis on study tours of the desert epigraphy has great potential in this area and could attract additional tourists.

Tourism Readiness

No visitor center, no restaurants, public toilets, or other tourism facilities currently exist in the village or on the site. The site lacks appropriate signage and interpretation. Accessibility also may prove problematic. Umm al Jimal can be reached by motor coach and automobile, but improvements are needed to increase highway capacity and parking. Given the low volume of tourism expected in the area, alternative accommodations should be provided in tents, pensions, and bed and breakfasts.

A survey of the village residents found that local citizens were pessimistic about the potential of tourism in the area. However, they offered several suggestions for increasing the volume of tourism, from overnight stays in local homes to desert tours on camel-back to overnight camping in traditional Bedouin tents hosted by local families.

\section{Conclusion}

The question of how to manage the invaluable cultural patrimony of Jordan by encouraging foreign investment and involvement and simultaneously preventing the destructive impacts of tourism is a vital one. The Jordanian patrimony is at danger of becoming a victim of commercialization in the areas chosen by foreign agencies for development. Tourist sites are prone to destruction due to the lack of visitor management techniques and lack of monitoring. Ignorance among the local communities and a lack of direct involvement may gradually lead to a complete loss of value systems prevalent locally. Additionally, the leakage of national capital via international agencies is a problem of great concern to the cultural resources managers who fear the continuing impact of tourism upon the cultural heritage. The Ministry of Tourism and Antiquity announced that $10 \%$ of the GDP comes from tourism, but the multiplier measurements indicate that it must be less than that. As to the northern part of Jordan, especially Umm al Jimal, the area's strengths are a distinctive, natural environment and a rich archaeological and cultural heritage. Weaknesses include seasonality of climate, lack of tourism facilities, isolation, and a poor transportation infrastructure. However, considerable opportunities in the low-volume, high-yield niche tourism market can still be realized. 


\subsection{Recommendations for Tourism Development in Umm al Jimal}

The community and tourism development plans for Umm al Jimal should meet the following conditions:

- The principles of Cultural Resource Management should guide development, safeguarding archaeology, heritage, and environment.

- Archaeology is the heart of this heritage site, and its excavation, restoration, conservation, and presentation is vital. The plan should preserve the monuments, restore the buildings, and keep the character of the site in harmony with its environment.

- The aesthetic value of the archaeological site must be respected and integrated into the planning, zoning, and architectural design of any new infrastructure.

- The manufacture of innovative new tourism products like high-value reproductions of heritage artifacts should be encouraged. Tourism products must exceed visitors' expectations. Products must be competitive in the international marketplace.

- The active participation of residents in the development process is central to sustainable development. Local residents must become stakeholders and beneficiaries of tourism development.

- The development of this site could (and should) have a measurable impact on employment and the standard of living of local residents.

- Sustainable development efforts must include public-private partnerships, as well as cooperation among several sectors of the Jordanian government.

Mohammed Shunnal is Professor of Anthropology at the Yarmouk University, Jordan. His main reseach areas include cultural resources, tourism, role of information technology in socio-cultural change, conservation of traditional buildings in the Middle East, emanzipation of women in the Middle East, and space and place and the dynamics of culture. 


\section{Literature}

Crick, Malcolm. 1989. Representations of International Tourism in the Social Sciences: Sun, Sex, Sights, Savings, and Servility. Annual Review of Anthropology 18: 307-344.

Cohen E. 1988. Alternative tourism- A Critique, in: Singh, T.V., H.L. Theuns and F.M. Co. (eds). Towards Appropriate Tourism: The Case of Developing Countries. Frankfurt: Peter Lang.

Cohen, E. 1992. Pilgrimage Centers: concentric and excentric. Annals of Tourism Research 19(1): $33-50$.

De Kadt, Emanuel (ed.). 1979. Tourism: Passport to Development? Perspectives on the Social and Cultural Effects of Tourism in Developing Countries. New York, London: Oxford University Press.

Din, Kadir H. 1989. Islam and Tourism: Patterns, Issues, and Options. Annals of Tourism Research 16(4): 542-63.

ESCWA (Economic and Social Commission for Western Asia). 2001. Challenges and Opportunities of WTO on Services in Selected ESCWA Member Countries: Tourism. United Nations, New York.

Farrell, Byran H. 1979. Tourism's Human Conflicts: Cases from the Pacific. Annals of Tourism Research 6: 122-36.

JICA (Japanese International Cooperation Agency) (2004). Comprehensive Basic Survey on Priority Areas of JICA Assistance.

Kuo, L. 2002. The Effectiveness of Environmental Interpretation at Resources-Sensitive Tourism Destination. International Journal of Tourism Research 4: 87-101.

Mason, P. 1997. Tourism Codes of Conduct in the Arctic and Sub-Arctic Region. Journal of Sustainable Tourism 5(2): 151-65.

McCool, S. and D. Lime. 2001. Tourism Carrying Capacity: Tempting Fantasy or Useful Reality. Journal of Sustainable Tourism 9(5): 372-88.

Mowforth, M. \& I. Munt. 2003. Tourism and Sustainability. London: Routledge.

Ministry of Tourism and Antiquities in Jordan. (2003). www.tourism.jo. Jordan National Tourism Strategy 2004-2010.

Ministry of Tourism and Antiquity. Tourism Statistical Bulletin. 2008. 4,4. www.locateme.jo/stat 2008/1/state.htm.

Natsios, Andrew S. 2008. The Role of Sustainable Tourism in Furthering USAID's Mission. United States Agency for International Development, World Tourism Organization: Sustainable Tourism Policy Forum.

Richter, Linda K. 1989. The Politics of Tourism in Asia. Honolulu: University of Hawaii Press.

Roudan, O. F. al-Ardah, and T. Bedour. 2000. Tourism Economics in Jordan: Essential Facilties and Marketing. Royal Scientific Society: Amman.

Shunnaq, Mohammed, William A. Schwab, Margaret F. Reid. 2008. Community Development Using a Sustainable Tourism Strategy: a Case Study of the Jordan River Valley Touristway. International Journal of Tourism Research 10: 1-14. 
Turner, Louis; John Ash. 1976. The Golden Hordes: International Tourism and the Pleasure Periphery. New York: St. Martin's Press.

United Nations World Tourism Organization (UNWTO). 2009. www.unwto.org/facts/eng/vision. htm.

USAID \& Sustainable Tourism: Meeting Development Objectives. 2009. www.usaid.gov/pdf_ docs/PNADE710.pdf. Accessed February 7, 2010. 